\title{
Assessing Chilling Conditions by Sites and Years for Perennial Fruit Production in Kentucky
}

\author{
Yao Xue, Sai Pavan Adigarla, Venkata Sravani Reddy Seethi, Elmer Gray \\ Department of Agriculture and Public Health, Western Kentucky University, Bowling Green, KY, USA \\ Email: elmer.gray@wku.edu
}

Received 7 June 2016; accepted 19 July 2016; published 22 July 2016

Copyright (C) 2016 by authors and Scientific Research Publishing Inc.

This work is licensed under the Creative Commons Attribution International License (CC BY).

http://creativecommons.org/licenses/by/4.0/

(c) () Open Access

\section{Abstract}

Temperate regions of the world are characterized by seasonal warm and cool temperature. Cool temperature enables the plant to undergo physiological processes essential for flowering and fruit bearing in the following season. Failure of environments to provide chilling conditions required for the fruit cultivar results in deformed leaves, fruits, or barren trees. The present study was conducted to assess production and distribution of chilling hours in Kentucky environments. Weather data were provided by Kentucky Mesonet system for 50 counties over a 5-year period. A chilling unit is defined as a clock hour in which air temperature is between $0^{\circ} \mathrm{C}$ and $7.2^{\circ} \mathrm{C}$. Temperature readings in this range were recorded from September through April. Average number of chilling hours observed in the study was 1556 overall, and ranged from 1463-1680 for sites, and 1473-1842 for years. Estimated chilling hours were more variable for years than for sites. Consistency of chilling results was high when measured by linear correlation and relative standard deviation statistical procedures. Accumulated chilling hours at the sites reached approximately 1000 by mid-January thereby meeting the requirements for many fruit crops. At that point, plants would be ready for bud break and become subject to freezing damage. The results indicated that chilling exceeded requirements for most Kentucky crops. This margin of excess has both negative and positive value. First, the plants become more vulnerable to freezing damage before winter weather is completed. The higher risk could be mitigated by growing cultivars with longer chilling requirements. Second, since warming has been shown to decrease chilling production, the margin of chilling hours could provide time for adjusting horticultural enterprises in Kentucky to global warming. Additional understanding of relationships between environments and chilling will contribute to perennial fruit production in temperate regions of the world.

\section{Keywords}

Climate, Weather, Global Warming, Plant Dormancy 


\section{Significance of Chilling Requirements in Fruit Production}

Since the origin of agriculture the essence of successful crop production has been matching crop requirements with environmental conditions. The chilling requirement of perennial fruit and nut crops grown in the temperate regions of the world has been studied for more than two centuries [1]. The chilling period begins with autumn leaf drop and continues until essential development processes are completed. Unless chilling requirements are met, leaf and flower production during the following season may be impaired resulting in lower yields or complete crop failure [2]. Chilling requirements are specific for plant species and cultivars within species. Chilling hour production varies with climatic conditions as expressed through both distribution and total accumulation of chilling hours. Kentucky's climate is favorable for production of a wide range of fruit and nut crops; however, fluctuating winter temperatures characteristic of the temperate region, are often damaging. Global warming is reducing chilling hours and resulting in concern about continued productivity of fruit crops [3].

\subsection{Chilling Hours Required by Different Crops}

Chilling requirements of crops vary among species and varieties within species [4]-[6]. In these reports chilling hour requirements ranged from 0 to 1800. Commonly grown Kentucky fruits and nuts included: apple 800 1700, pears 600 - 1400, peaches $200-1200$, blueberries 650 - 1400, cherries $500-1400$, grapes $100-500$, and almonds 200 - 500. Parker and Werner tested chilling requirements for 112 peach varieties in North Carolina and found a range of 550 to 1050, mean of 824 and bimodal at 750 and 850 [7].

\subsection{Chilling Hours Produced by Different Environments}

In early studies of chilling requirements of fruit and nut crops grown in California, several factors were found to influence chilling conditions of environment [8]. Factors enhancing chilling included: colder and longer winters, a period of hardening or transition into slower growth, adequate moisture and temperature for post-budbreak, and shading or winter fog that kept temperature cooler. Taylor used current and historically synthesized chilling data, based upon the regression relationship between weather data and chilling hours, to compute chill hours for Byron, Georgia [9]. The average number of chill hours for the 63-year period (1937 through 1990) was 1189. Winter chilling period measurements began October $1^{\text {st }}$ and continued through February $28^{\text {th }}$ each year. Average percentage chilling hour accumulations for the months were: October (3.0\%), November (17.6\%), December (45.8\%), January (77.0\%), February (100\%). For the 1940s through 1990s, total accumulated hours averaged by decade were 1940s (1127), 1950s (1146), 1960s (1313), 1970s (1194), 1980s (1197), 1990s (1082). Parker and Werner [7] reported that the peach production region of North Carolina usually received in excess of 1000 chilling hours annually. Luedeling and Brown [10] recommended that data on chilling requirements should be supported by weather information on the location and condition of the site. They incorporated daily minimum and maximum temperatures, precipitation data, and occurrence of dry and wet periods in calculating site parameters.

\subsection{Chilling Hours and Global Warming}

Major climate models are projecting progressively rising temperature. In California, climate trends indicated that chilling hours were decreasing by 50 to 260 per decade, resulting in the prediction of $<500$ per year by the end of $21^{\text {st }}$ century for some locations. These winter chill levels will be insufficient for continued production of many fruits and nuts. Existing and newly established orchards will not be fully productive even though other conditions are favorable [5]. Luedeling compared chilling at six sites in California's Central Valley [3]. Their results for years 1950 and 2000 were as follows (1950 first, 2000 second): Davis (1112, 1007), Hollister (894, 833), Red Bluff (1221, 1179), Shafter $(1127,1096)$, Tracy $(1054,903)$, Winters $(1277,995)$. Chilling hours varied by location and decreased by year. According to Climate Change 2014 Synthesis Report by the Intergovernmental Panel on Climate Change, warming of the climate system is unequivocal [11]. This change in temperature is expected to result in more frequent hot and fewer cold extremes over most land surfaces. Luedeling et al. calculated a decrease of 1.2 - 9.5 chilling hours per year for high elevation oases of Oman, Arabian Peninsula [6]. Fruit production by most traditionally grown trees was found to be marginal due to limiting chill hours.

Objectives of the present study were to develop an inventory of chilling potential for different Kentucky environments for use by present and future horticulturalists and to establish a base level of chilling as reference for 
assessing changes due to global warming.

\section{Materials and Methods}

Weather data were provided by Kentucky Mesonet, the state's official source for weather and climate data. One Mesonet site was located in 50 of 120 Kentucky counties (Table 1, Figure 1). Individual sites had been selected as representative of the area, unobstructed by natural or constructed barriers, and accessible. Site distribution included the state's three Plant Hardiness Zones (6a, 6b, 7a) [12] and its four Climate Divisions (Western, Central, Bluegrass, and Eastern) [13]. Each Mesonet site was equipped with three thermometry's (PRTs) for measuring air temperature at $1.5 \mathrm{~m}$ above ground. These units were averaged into 5-minute temperature values, which were further combined into one-hour periods for the chilling study.

The Chilling Hours Model was used to convert clock hours into chilling hours [10] [11]. Each clock hour with temperature between $0^{\circ} \mathrm{C}-7.2^{\circ} \mathrm{C}$ was counted as a chilling hour. Chill temperature recordings began September 1 and continued through April 30. All weather data were based upon this 8-month period and were specific for site and year. Data for combination of 50 sites over 5 years were analyzed for total chilling hour production by site and year using the analysis of variance and Tukey's test. Consistency of production distributions over sites and over months within year were compared using linear correlation and relative standard deviation (RSD) [14] [15]. Correlation was used to estimate the relationships between chilling hours production and the quantified physiographical characteristics of the sites. Also, correlations were calculated between chilling hours production over successive years of the five-year period plus up to eight years at sites where additional data were available.

\section{Results}

Mesonet site characteristics are presented in Table 1, Figure 1. The 50 sites were located within ranges of $2.39^{\circ}$

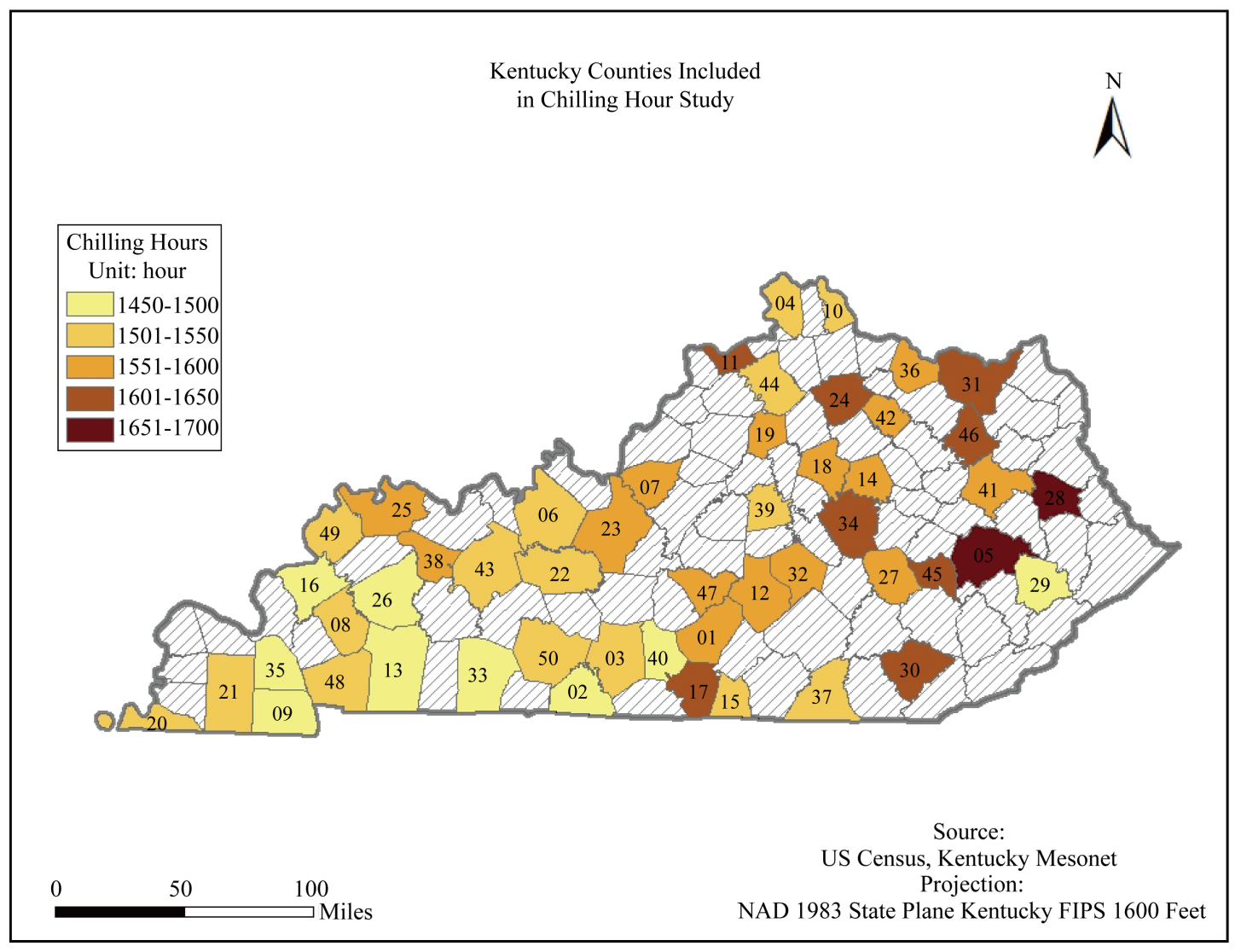

Figure 1. Color-coded location of the 50 counties with a Mesonet site (county numbers match site numbers in Table 1). 
Table 1. Identification, location, and environmental data for 50 Kentucky Mesonet sites included in the 5-year (2010-2011 through 2014-2015) chilling study ${ }^{\mathrm{a}}$.

\begin{tabular}{|c|c|c|c|c|c|c|c|c|c|}
\hline \multicolumn{2}{|r|}{ Site } & \multicolumn{2}{|c|}{ Coordinates } & \multirow{2}{*}{$\begin{array}{c}\text { Elevation } \\
\text { (m) }\end{array}$} & \multirow{2}{*}{$\begin{array}{l}\text { Ppt } \\
\text { (cm) }\end{array}$} & \multirow{2}{*}{$\begin{array}{l}\text { Temp } \\
\left({ }^{\circ} \mathrm{C}\right)\end{array}$} & \multirow{2}{*}{$\begin{array}{c}\text { Freezing } \\
\left(<0^{\circ} \mathrm{C}\right)\end{array}$} & \multirow{2}{*}{$\begin{array}{l}\text { Chilling }{ }^{\mathrm{b}} \\
\left(0 \text { to } 7.2^{\circ} \mathrm{C}\right)\end{array}$} & \multirow{2}{*}{ RSD (\%) } \\
\hline Id & County & Lat $\left({ }^{\circ}\right)$ & Long( $\left.{ }^{\circ}\right)$ & & & & & & \\
\hline 1 & Adair & 37.14 & -85.29 & 258 & 88 & 9 & 967 & 1552 & 11 \\
\hline 2 & Allen & 36.74 & -86.22 & 249 & 85 & 9 & 874 & 1464 & 10 \\
\hline 3 & Barren & 37.01 & -86.11 & 212 & 87 & 9 & 939 & 1527 & 10 \\
\hline 4 & Boone & 38.96 & -84.72 & 273 & 85 & 7 & 1333 & 1508 & 16 \\
\hline 5 & Breathitt & 37.54 & -83.34 & 209 & 86 & 8 & 1032 & 1680 & 10 \\
\hline 6 & Breckinridge & 37.71 & -86.49 & 212 & 84 & 8 & 1142 & 1523 & 10 \\
\hline 7 & Bullitt & 37.92 & -85.66 & 166 & 83 & 8 & 1095 & 1572 & 10 \\
\hline 8 & Caldwell & 37.10 & -87.86 & 155 & 86 & 9 & 1047 & 1521 & 10 \\
\hline 9 & Calloway & 36.61 & -88.34 & 173 & 95 & 9 & 878 & 1499 & 12 \\
\hline 10 & Campbell & 39.01 & -84.47 & 255 & 78 & 7 & 905 & 1544 & 15 \\
\hline 11 & Carroll & 38.69 & -85.14 & 143 & 84 & 7 & 1225 & 1632 & 11 \\
\hline 12 & Casey & 37.28 & -84.96 & 291 & 91 & 8 & 1075 & 1595 & 14 \\
\hline 13 & Christian & 36.95 & -87.52 & 222 & 87 & 9 & 977 & 1463 & 15 \\
\hline 14 & Clark & 38.03 & -84.20 & 296 & 79 & 8 & 1204 & 1579 & 12 \\
\hline 15 & Clinton & 36.71 & -85.13 & 310 & 91 & 9 & 915 & 1522 & 10 \\
\hline 16 & Crittenden & 37.38 & -88.04 & 181 & 89 & 9 & 1031 & 1495 & 11 \\
\hline 17 & Cumberland & 36.80 & -85.43 & 167 & 85 & 8 & 977 & 1636 & 10 \\
\hline 18 & Fayette & 37.97 & -84.53 & 318 & 85 & 8 & 1166 & 1555 & 12 \\
\hline 19 & Franklin & 38.12 & -84.88 & 227 & 85 & 8 & 1188 & 1571 & 11 \\
\hline 20 & Fulton & 36.57 & -89.15 & 105 & 90 & 9 & 952 & 1526 & 11 \\
\hline 21 & Graves & 36.69 & -88.72 & 132 & 88 & 9 & 1020 & 1519 & 10 \\
\hline 22 & Grayson & 37.46 & -86.34 & 220 & 88 & 8 & 1154 & 1532 & 10 \\
\hline 23 & Hardin & 37.67 & -85.97 & 227 & 81 & 8 & 1141 & 1573 & 12 \\
\hline 24 & Harrison & 38.49 & -84.34 & 200 & 75 & 7 & 1387 & 1623 & 10 \\
\hline 25 & Henderson & 37.82 & -87.50 & 156 & 81 & 8 & 1206 & 1571 & 11 \\
\hline 26 & Hopkins & 37.27 & -87.48 & 180 & 84 & 9 & 966 & 1463 & 11 \\
\hline 27 & Jackson & 37.36 & -83.97 & 402 & 92 & 8 & 1144 & 1587 & 9 \\
\hline 28 & Johnson & 37.83 & -82.88 & 230 & 83 & 7 & 1190 & 1662 & 10 \\
\hline 29 & Knott & 37.40 & -82.99 & 474 & 77 & 8 & 1037 & 1474 & 11 \\
\hline 30 & Knox & 36.87 & -83.83 & 309 & 96 & 9 & 932 & 1613 & 11 \\
\hline 31 & Lewis & 38.58 & -83.42 & 166 & 81 & 7 & 1229 & 1632 & 10 \\
\hline 32 & Lincoln & 37.58 & -84.62 & 297 & 85 & 8 & 1116 & 1600 & 10 \\
\hline 33 & Logan & 36.85 & -86.92 & 201 & 93 & 9 & 972 & 1466 & 10 \\
\hline 34 & Madison & 37.72 & -84.15 & 262 & 82 & 8 & 1197 & 1607 & 8 \\
\hline
\end{tabular}




\begin{tabular}{cccccccccc} 
Continued & & & & & & & & & \\
\hline $\mathbf{3 5}$ & Marshall & 36.92 & -88.34 & 142 & 92 & 9 & 927 & 1499 & 12 \\
$\mathbf{3 6}$ & Mason & 38.62 & -83.81 & 277 & 79 & 7 & 1295 & 1595 & 12 \\
$\mathbf{3 7}$ & McCreary & 36.77 & -84.47 & 399 & 98 & 9 & 942 & 1537 & 11 \\
$\mathbf{3 8}$ & Mclean & 37.59 & -87.32 & 123 & 78 & 8 & 1113 & 1565 & 11 \\
$\mathbf{3 9}$ & Mercer & 37.81 & -84.84 & 273 & 81 & 8 & 1134 & 1533 & 11 \\
$\mathbf{4 0}$ & Metcalf & 36.98 & -85.70 & 305 & 90 & 9 & 945 & 1496 & 10 \\
$\mathbf{4 1}$ & Morgan & 37.90 & -83.27 & 326 & 78 & 8 & 1107 & 1594 & 12 \\
$\mathbf{4 2}$ & Nicholas & 38.27 & -84.10 & 286 & 76 & 7 & 1244 & 1590 & 13 \\
$\mathbf{4 3}$ & Ohio & 37.46 & -86.86 & 163 & 83 & 8 & 1078 & 1513 & 12 \\
$\mathbf{4 4}$ & Owen & 38.55 & -84.74 & 265 & 83 & 7 & 1289 & 1542 & 13 \\
$\mathbf{4 5}$ & Owsley & 37.45 & -83.68 & 238 & 84 & 8 & 1038 & 1627 & 10 \\
$\mathbf{4 6}$ & Rowan & 38.22 & -83.48 & 259 & 83 & 7 & 1223 & 1648 & 11 \\
$\mathbf{4 7}$ & Taylor & 37.36 & -85.46 & 239 & 91 & 8 & 1070 & 1580 & 11 \\
$\mathbf{4 8}$ & Trigg & 36.82 & -87.86 & 153 & 91 & 9 & 960 & 1533 \\
$\mathbf{4 9}$ & Union & 37.69 & -87.84 & 134 & 83 & 8 & 1084 & 1533 \\
$\mathbf{5 0}$ & Warren & 36.93 & -86.47 & 170 & 84 & 9 & 943 & 1549 & 11 \\
& Mean & & & $\mathbf{2 2 8}$ & $\mathbf{8 4}$ & $\mathbf{8}$ & $\mathbf{1 0 5 9}$ & $\mathbf{1 5 5 7}$ \\
\hline
\end{tabular}

${ }^{\mathrm{a} P p t}$, Temp, Freezing, and Chilling data were based up on 8 months (September through April) for 5 years (2010-11 to 2014-15); ${ }^{\mathrm{b}} \mathrm{Critical}$ value (Tukey's W) for chilling sites $=16$. Difference between two site means greater than 16 indicates significance at $(\mathrm{P} \leq 0.05)$.

(36.57 to 38.96) latitude and $6.27^{\circ}$ (-82.88 to -89.15$)$ longitude. Elevation of sites varied $369 \mathrm{~m}$ (105 - 474). For the 8-month chilling period (September-April), precipitation over all sites and years averaged $84 \mathrm{~cm}$ and ranged from 75 - $98 \mathrm{~cm}$ among sites. Mean air temperature for sites over the 5-year chilling periods was $8^{\circ} \mathrm{C}$ and varied from $7^{\circ} \mathrm{C}-9^{\circ} \mathrm{C}$. The number of hours in which air temperature was below freezing averaged 1059 and ranged from 874 to 1389 for sites.

\subsection{Chilling Hour Production by Sites}

Total chilling hour production for the sites over the 5-year period averaged 1557 and ranged from 1463 - 1680 . Sites differed significantly for chilling hour production $(\mathrm{P} \leq 0.05)$ (Table 1$)$ and, in general, were higher in the Eastern climate division, intermediate in the Central and Bluegrass divisions, and lowest in the Western division. The pattern was similar for plant hardiness zones. Most observed chilling hours near or above 1600 were in zone 6a located in the north-north east, whereas lowest production was in zone 7a located in the south-south west.

\subsection{Chilling Hour Production within Years}

Mean chilling production by year varied from 1473 - 1842 with the difference between all possible pairs of year means exceeding the critical value for significance at the 0.05 level. There was no apparent trend among the year means (Table 2). Monthly distribution for chilling hour production within years over sites is summarized in Table 2. Production began in September and continued through April with most production occurring from November through March.

\subsection{Chilling Hour Production over Sites and Years}

Correlations between each site's production with the total production of the other 49 sites were used as estimates of consistency. All r values were positive and significant. The lowest $r(0.870)$ gave a coefficient of determination $\left(\mathrm{r}^{2}\right)$ of $75.6 \%$ indicating high consistency among sites for total chilling production. For monthly distribution 
Table 2. Mean annual production and within year distribution of chilling hours for 5 years (2010-2011 through 2014-2015) at 50 Kentucky Mesonet sites.

\begin{tabular}{|c|c|c|c|c|c|c|c|c|c|c|}
\hline \multirow[t]{2}{*}{ Year } & \multicolumn{8}{|c|}{ Monthly distribution $^{a}$} & \multirow[b]{2}{*}{ Year mean ${ }^{\mathrm{b}}$} & \multirow[b]{2}{*}{ RSD $\%$} \\
\hline & Sep & Oct & Nov & Dec & Jan & Feb & Mar & Apr & & \\
\hline 2010-2011 & 2.3 & 88.8 & 275.3 & 184.2 & 259.4 & 243 & 346.9 & 72.9 & 1473 & 4.1 \\
\hline 2011-2012 & 0.9 & 135.4 & 203.4 & 376.8 & 309.1 & 302.1 & 107.3 & 102.1 & 1537 & 4.9 \\
\hline 2012-2013 & 18.2 & 146.4 & 315.2 & 265.5 & 249.8 & 328 & 371.3 & 147.8 & 1842 & 3.6 \\
\hline 2013-2014 & 0.68 & 119.7 & 255.3 & 267.4 & 223.5 & 182 & 287.3 & 88.2 & 1424 & 5.7 \\
\hline 2014-2015 & 3.6 & 86.5 & 266.8 & 404.2 & 282.5 & 150.6 & 232.5 & 79.6 & 1506 & 3.8 \\
\hline Mean & 5.14 & 115.36 & 263.2 & 299.62 & 264.86 & 241.14 & 269.06 & 98.12 & 1556 & \\
\hline$\%$ & $<1$ & 7.0 & 17.0 & 19 & 17.0 & 16.0 & 19.0 & 6.0 & 100 & \\
\hline
\end{tabular}

${ }^{\mathrm{a} E a c h}$ value is the mean of 50 sites; ${ }^{\mathrm{b}}$ Critical value (Tukey's W) for years $=26$. Difference between year means greater than 26 indicates significance at $(\mathrm{P} \leq 0.05)$.

all $r$ values were positive and significant. The lowest $r(0.964)$ showed that $92.9 \%$ of the variation in that individual site was in common with the average variation for the other 49 sites. Comparisons of individual year means with means for the other four years resulted in r-values that were all positive and significant. For total chilling production, r-value ranged from 0.683 - 0.945, for monthly distribution the range was $0.774-0.970$. Also, consistency was high as evidenced by low RSD values, which ranged from 8 to 16\% for sites over years (Table 1) and from 3.6 to 5.7\% for years over sites (Table 2). Annual chilling hour production and distribution were highly consistent over sites and years included in the study.

Relationships between chilling hour production and physiographical characteristics of the sites were examined using linear correlation. For significance at the 0.05 , an r-value of 0.276 or greater is required. Site elevation ranged from 105 to 474 meters. The r-value of 0.031 gave no indication of any impact of elevation difference on chilling hour production. Mean precipitation and chilling production were negatively related $(\mathrm{r}=$ $-0.269, \mathrm{P} \leq 0.05)$, mean air temperature and chilling production were negatively associated $(\mathrm{r}=-0.596, \mathrm{P} \leq$ 0.05), mean freezing hours and chilling were positively correlated $(r=0.475, P \leq 0.05)$. The relationship between chilling hours and advancing years, within the five year period and up to eight years when extended data were available, was not significant $(r=0.100)$.

\section{Discussion and Summary}

Kentucky has a temperate region environment suitable for perennial fruit and nut production. The comparative advantages include mild winter and summer temperature, adequate amount and distribution of precipitation, and productive soils. Area vegetation includes a broad range of both northern and southern plant species. However, perennial fruit production in the area is erratic. It is hypothesized that the inconsistency in fruit production results from adverse chilling conditions. Also, the threat of global warming and its effect on chilling conditions for fruit and nut crops grown in this environment has not been established. The results are based upon data collected over 5 years at 50 Kentucky sites and can be considered only as preliminary in meeting the study objectives.

Study results indicated that total and distribution of chilling production for sites and years appeared adequate for fruit production. Overall, total chilling hour production ranged from 1463 - 1680, which exceed requirements for Kentucky grown fruit crops [4]. This margin of chilling hours could provide a temporary buffer against global warming which decreases chilling production [3].

Inconsistent production over years is likely due to cultivar selection. Crops such as apples and peaches fulfill their chilling requirement early in the winter, thereby ending the freezing protection provided by dormancy of the buds. At that point, the buds open and become vulnerable to freezing damage during alternating warm and cold temperatures for the remainder of the winter. For North Carolina, Parker and Werner [7] found that the mean and mode chilling accumulation required for peach cultivars were approximately 800 hours which occurred about mid-January, ending bud dormancy protection and leaving two or three months in which open buds were subject to freezing. Kentucky’s situation appears analogous. Potential freezing damage can be mitigated by 
selecting cultivars with higher chilling requirements, thereby adding to the importance of the emerging practice of nurseries' reporting chilling requirements with fruit and nut crop propagative materials.

Although there were significant differences in average number of chilling hours among sites and among years, high levels of consistency were observed among sites over years and among years over sites. There were subsets within sites that did not differ significantly, whereas mean chilling hour production for each year differed significantly from the means of the other years.

Relationships between chilling hour production and physiographic characteristics of the sites were variable and low, likely reflecting insufficient numbers of observation during the 5-year period of data collection.

\section{Conclusion}

Successful fruit and nut production requires that crops be matched to the environment. Kentucky growers need more information on chilling requirements of their nursery stocks and chilling production of their environments. Warming temperature is threatening long-established relationships among production factors. Necessary changes involving perennial orchards are expensive and time consuming. Meanwhile, established practices of planting orchards near large bodies of water or higher elevation should be followed to reduce the frequency of brief warming period resulting in bud breaks. Research and understanding of the environmental conditions supporting chilling plus nursery information on fruit plant requirements will enhance fruit production in temperate regions of the world.

\section{Acknowledgements}

Appreciation is expressed to Dr. Stuart A. Foster, State Climatologist for weather data provided by the Kentucky Climate Center through Kentucky Mesonet. Special thanks are extended to David W. Pedigo and Jesse N. Winchester for technical assistance with data collection and processing. Support of the Departments of Agriculture and Public health, the College of Science and Engineering, and the Office of University Provost is greatly acknowledged. Response to the reviewers comments added value to the manuscript.

\section{References}

[1] Baldocchi, D. and Wong, S. (2007) Accumulated Winter Chill Is Decreasing in the Fruit Growing Regions of California. Climate Change, 87, S153-S166. http://dx.doi.org/10.1007/s10584-007-9367-8

[2] Chandler, W.H., Kimball, M.H., Philp, G. L., Tufts, W.P. and Weldon, G.P. (1937) Chilling Requirements for Opening of Buds on Deciduous Orchard Trees and Some Other Plants in California. Bul. 611, Agricultural Experiment Station, Berkeley.

[3] Hartmann, H.T., Kofranek, A.M., Rubatzky, V.E. and Flocker, W.J. (1988) Plant Science: Growth, Development and Utilization of Cultivated Plants. 2nd Edition, Prentice Hall, Eaglewood Cliffs.

[4] IPCC (2014) Climate Change 2014: Synthesis Report. International Panel on Climate Change, Geneva, Switzerland.

[5] Knight, T.A. (1801) Account of Some Experiments on the Ascent of the Sap in Trees. Philosophical Transactions of the Royal Society of London, 91, 333-353. http://dx.doi.org/10.1098/rstl.1801.0017

[6] Luedeling, E. and Brown, P.H. (2011) A Global Analysis of the Comparability of Winter Chill Models for Fruit and Nut Trees. International Journal of Biometeorology, 55, 411-421. http://dx.doi.org/10.1007/s00484-010-0352-y

[7] Luedeling, E., Gebaurt, J. and Buerkert, A. (2009) Climate Change Effects on Winter Chill for Tree Crops with Chilling Requirements on the Arabian Peninsula. Climatic Change.

[8] Luedeling, E., Zhang, M. and Girvetz, E.H. (2009) Climatic Changes Lead to Declining Winter Chill for Fruit and Nut Trees in California during 1950-2099. PLOS One, 4, e6166.

[9] Leudeling, E., Zhang, M., Leudeling, V. and Girvetz, E.H. (2009) Sensitivity of Winter Chill Models for Fruit and Nut Trees to Climate Changes Expected in Califronia’s Central Valley. Agriculture, Ecosystems and Environment, 133, 23-31. http://dx.doi.org/10.1016/j.agee.2009.04.016

[10] Leudeling, E., Zhang, M., McGranahan, G. and Leslie, C. (2009) Validation of Winter Chill Models Using Historic Records of Walnut Phenology. Agriculture and Forest Meteorology, 149, 1854-1864. http://dx.doi.org/10.1016/j.agrformet.2009.06.013

[11] Parker, M.L. and Werner, D.J. (1993) Chilling Requirements of Selected Peach Varieties. North Carolina Cooperative Extension, Leaflet No: 327. 
[12] Steel, R.G.D. and Torrie, J.H. (1980) Principles and Procedures of Statistics. 2nd Edition, McGraw-Hill, Inc., New York.

[13] Taylor, K.C. (2011) Peaches. Retrieved from New Georgia Encyclopedia: http://www.georgiaencyclopedia.org/articles/business-economy/peaches

[14] (2012) USDA Plant Hardiness Zone Map. Retrieved from United States Department of Agriculture: http://planthardiness.ars.usda.gov/PHZMWeb/

[15] (2012) USDA Census of Agriculture. Retrieved from United States Department of Agriculture: http://www.agcensus.usda.gov/

\section{Submit or recommend next manuscript to SCIRP and we will provide best service for you:}

Accepting pre-submission inquiries through Email, Facebook, LinkedIn, Twitter, etc.

A wide selection of journals (inclusive of 9 subjects, more than 200 journals)

Providing 24-hour high-quality service

User-friendly online submission system

Fair and swift peer-review system

Efficient typesetting and proofreading procedure

Display of the result of downloads and visits, as well as the number of cited articles

Maximum dissemination of your research work

Submit your manuscript at: http://papersubmission.scirp.org/ 